Journal of Southeast Asian

\title{
Three Poems: On The Artist's Mother, Sleeping; Reverberations; 4 Found Haiku
}

Jenna Le

jenna.le@gmail.com

Follow this and additional works at: https://docs.lib.purdue.edu/jsaaea

Part of the Bilingual, Multilingual, and Multicultural Education Commons

\section{Recommended Citation}

Le, Jenna (2021) "Three Poems: On The Artist's Mother, Sleeping; Reverberations; 4 Found Haiku," Journal of Southeast Asian American Education and Advancement: Vol. 16 : Iss. 1, Article 3.

DOI: $10.7771 / 2153-8999.1231$

Available at: https://docs.lib.purdue.edu/jsaaea/vol16/iss1/3

This document has been made available through Purdue e-Pubs, a service of the Purdue University Libraries. Please contact epubs@purdue.edu for additional information.

This is an Open Access journal. This means that it uses a funding model that does not charge readers or their institutions for access. Readers may freely read, download, copy, distribute, print, search, or link to the full texts of articles. This journal is covered under the CC BY-NC-ND license. 


\section{JSAAEA Journal of Southeast Asian American
Education and Advancement}

Vol. 16 Iss. 1 (2021)

Www.JSAAEA.org

Creative and Literary Works

Three Poems

Jenna Le

On The Artist's Mother, Sleeping (1911) by Egon Schiele

If I were to paint my own dear mother,

I wouldn't use such lush fruit-aisle colors.

Her flesh is more relaxed about the jaws.

Her hair for many years has been more sparse.

She never folds pale hands, Madonna-like, on thighs resembling sticks of dynamite.

Her pillow is no rippled square of nori:

instead, her bedding is pastel, unstoried.

What's more, her sleep is never quite so sound

a watercolorist could safely pounce

on her asparagus extent, imbuing

what he sees with plum and melon hues.

Like Whale's eye at the porthole, Mother's eye is always, always watching: red-rimmed, spry.

\footnotetext{
(9)

SDDERIGHISRESERNEDReaders are free to copy, display, and distribute this article, as long as the work is attributed to the author(s) and the Journal of Southeast Asian American Education \& Advancement, it is distributed for non-commercial purposes only, and no alteration or transformation is made in the work. More details of this Creative Commons license are available at http://creativecommons.org/licenses/by-nc-nd/3.0/. All other uses must be approved by the author(s) or JSAAEA. Journal of Southeast Asian American Education \& Advancement, Vol. 16. Iss. 1. (2021) ISSN: 2153-8999
} 


\section{Reverberations}

Snow coats the sloped roof. No ravage, no rampage,

no rage: in place of yesterday's WINTER STORM WARNING,

this is

simply morning. No blizzard,

unless you mean

the snowstorm of whispers

on an ultrasound machine's

pixeled, pixie-filled screen.

Someone mounded this snow on the tiles

the way a doctor in an aqua smock

heaps goo from a bottle on a girl's belly:

to see inside.

The fog's rocker-bottom feet

walk heavy on our skulls. There's someone

trying to see inside us,

to tell us

we're healthier than we know.

\section{Found Haiku, Based on Anti-Asian-Immigrant Pamphlets From 1902-1922}

Anti-Immigrant Mass Meeting!

(Rev. Little \& Col. Petit

will speak.)

Anti-Immigrant Mass Meeting!

(The Boys' Choir

will provide the music.)

They came to care for lawns

(the pests!). They want to build a church

(the heathens!).

Anti-Immigrant Mass Meeting!

(Everybody Invited.

Seats Free.) 


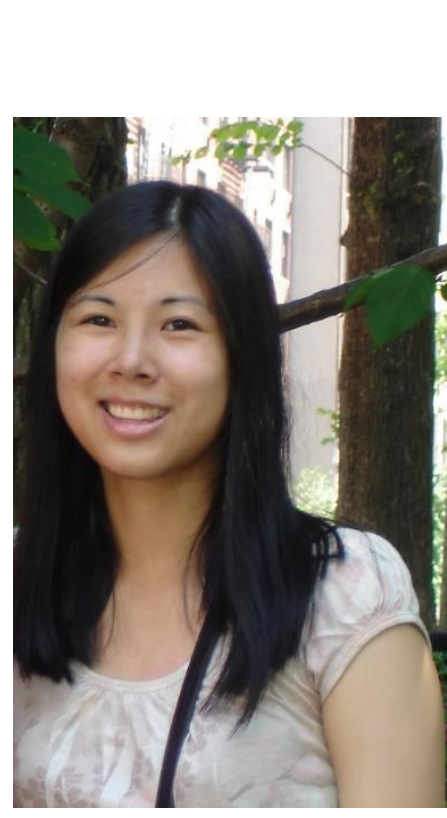

\section{About the Author}

Jenna Le is the author of Six Rivers (NYQ Books, 2011) and A History of the Cetacean American Diaspora (Indolent Books, 2018), a 2nd Place winner in the Science Fiction and Fantasy Poetry Association's Elgin Awards. A two-time winner of the Poetry By The Sea Sonnet Competition. She has had poems appear in AGNI, Denver Quarterly, Los Angeles Review, Massachusetts Review, Michigan Quarterly Review, Pleiades, Poet Lore, Verse Daily, and West Branch. She has a B.A. in math and a M.D. and lives and works as a physician in New York. 


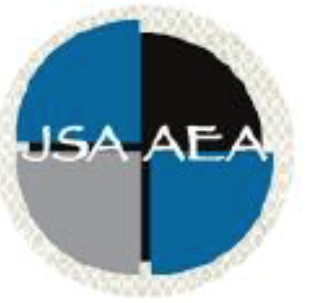

Vol.16 Iss.1 (2021)

\title{
Journal of Southeast Asian American Education and Advancement
}

\author{
WWW.JSAAEA.org
}

\section{Editor}

Dr. Wayne E. Wright

Purdue University

Associate Editors

Dr. Chhany Sak-Humphry

University of Hawaii at Manoa

Dr. Phitsamay Sychitkokhong Uy

University of Massachusetts, Lowell

\author{
Book Review Editor \\ Dr. Vichet Chhuon \\ University of Minnesota \\ Creative Works Editor \\ Bryan Thao Worra \\ Lao Assistance Center \\ Journal Manager \\ Chen Li \\ Jeffrey Sovan Wright \\ Purdue University
}

\section{Editorial Review Board}

\author{
Dr. Steve Arounsack \\ California State University, Stanislaus \\ Dr. Sovicheth Boun \\ Salem State University \\ Dr. Virak Chan \\ Purdue University \\ Dr. Loan Dao \\ University of Massachusetts Boston
}

\author{
Dr. Carl L. Bankston III \\ Tulane University \\ Dr. Phala Chea \\ Lowell Public Schools \\ Dr. George Chigas \\ University of Massachusetts, Lowell \\ Dr. Hien Duc Do \\ San Jose State University
}




\author{
Dr. Linh Dang \\ KIPP DC Headquarters \\ Dr. Sophal Ear \\ Occidental College \\ Dr. Vincent K. Her \\ University of Wisconsin, Eau Claire \\ Dr. Nancy H. Hornberger \\ University of Pennsylvania \\ Dr. Peter Tan Keo \\ New York University \\ Dr. Yvonne Kwan \\ San Jose State University \\ Dr. Ravy Lao \\ California State University, Los Angeles \\ Dr. Stacey Lee \\ University of Wisconsin, Madison \\ Dr. Jacqueline Mac \\ Northern Illinois University \\ Dr. Bic Ngo \\ University of Minnesota \\ Dr. Leakhena Nou \\ California State University, Long Beach \\ Dr. Mark Pfeifer \\ SUNY Institute of Technology \\ Dr. Loan T. Phan \\ University of New Hampshire \\ Dr. Karen Quintiliani \\ California State University, Long Beach \\ Dr. Angela Reyes \\ Hunter College \\ The City University of New York \\ Dr. Fay Shin \\ California State University, Long Beach \\ Dr. Christine Su \\ College of San Mateo \\ Dr. Alisia Tran \\ Arizona State University \\ Dr. Khatharya Um \\ University of California, Berkeley \\ Dr. Kim Tran \\ University of California, Los Angeles, \\ Glendale Community College \\ Dr. Molly Wiebe \\ The University of Texas at Austin \\ Dr. Changming Duan \\ University of Missouri-Kansas City \\ Dr. Sothy Eng \\ Lehigh University \\ Dr. Jeremy Hein \\ University of Wisconsin, Eau Claire \\ Dr. Peter Nien-Chu Kiang \\ University of Massachusetts, Boston \\ Dr. Kevin K. Kumashiro \\ University of Illinois, Chicago \\ Dr. Ha Lam \\ Independent Scholar \\ Dr. Jonathan H. X. Lee \\ San Francisco State University \\ Dr. Monirith Ly \\ Royal University of Phnom Penh \\ Dr. Sue Needham \\ California State University, Dominguez Hills \\ Dr. Max Niedzwiecki \\ Daylight Consulting Group \\ Dr. Clara Park \\ California State University, Northridge \\ Dr. Giang Pham \\ University of Massachusetts Amherst \\ Dr. Malaphone Phommasa \\ University of California Santa Barbara \\ Dr. Kalyani Rai \\ University of Wisconsin-Milwaukee \\ Dr. Cathy J. Schlund-Vials \\ University of Connecticut, Storrs \\ Dr. Nancy J. Smith-Hefner \\ Boston University \\ Dr. Yer J. Thao \\ Portland State University \\ Dr. Monica M. Trieu \\ Purdue University \\ Dr. Silvy Un \\ Saint Paul Public Schools \\ Dr. Linda Trinh Vo \\ University of California, Irvine \\ Dr. Varaxy Yi Borromeo \\ California State University, Fresno \\ Dr. Yang Sao Xiong \\ The University of Wisconsin-Madison

\section{Dr. Zha Blong Xiong} \\ University of Minnesota
}




\section{Doctoral Student Editorial Review Board}

Diana Chandara
University of Minnesota-Twin Cities
Bao Diep
University of Minnesota-Twin Cities
Vanessa Sovanika Na
University of California San Diego
Khoi Nguyen
George Mason University
Hoa Nha Nguyen
Boston College
Linda Marie Pheng
University of Wisconsin-Madison
Latana Thaviseth
University of California Los Angeles
Melissa Vang
San Diego State University

Diana Chandara

Bao Diep

rsity of Minnesota-Twin Cities

y of California San Diego

rge Mason University

Hoa Nha Nguyen

Boston College

rsity of Wisconsin-Madison

ty of California Los Angeles

San Diego State University

\author{
Kassandra Chhay \\ University of Minnesota-Twin Cities \\ Annie BichLoan Duong \\ San Joaquin County Office of Education \\ Nielson Hul \\ Cornell University \\ Dung Minh Mao \\ University of Minnesota-Twin Cities \\ Thien-Huong Ninh \\ University of Southern California \\ Krissyvan Truong \\ Claremont Graduate University \\ Mai Vang \\ University of Massachusetts Boston \\ Thong Vang \\ University of Minnesota-Twin Cities
}

Soua Xiong

San Diego State University

Claremont Graduate University 